\title{
Domestic Investment and Foreign Direct Investment Flows In Nigeria
}

\author{
Moses, C. Olise ${ }^{1}$, Anigbogu, Theresa $\mathrm{U}^{2}$. (Ph.D.), Okoli, Moses I. ${ }^{3}$ and \\ Anyanwu, Kingsley N. ${ }^{4}$ \\ ${ }^{1}$ Department of Marketing, Nnamdi Azikiwe University (NAU): \\ ${ }^{2}$ Department of Cooperative Economics and Management, NAU: \\ ${ }^{3}$ Department of Cooperative Economics and Management, NAU: \\ ${ }^{4}$ Department of Economics, $N A U^{*}$
}

\begin{abstract}
In the heat of the scramble of externally injected fund- Foreign Direct Investment- especially among developing economies, a mound body of literature has sprung up to investigate and unravel the theoretical plausibility of the rationale behind FDI; the traditional, or contemporary, determinants of FDI; and, of recent, the causative pattern of FDI and some core macro-variable. This paper took an interesting turn to investigate the impact of domestic investment on FDI inflows in Nigeria. Adopting a decomposed, single-linear econometric model estimated by the OLS methodology within four decade $11970-2009\}$, and after subjecting the data set through series of preliminary tests, the findings were robust: private and public domestic investments as well as human capital and market size are negatively related to FDI inflows, while trade openness and natural resource are positively linked to FDI. Thus, being proponents advocating for more FDI, the policy implications engendered by these findings, in a peculiar manner of writing, is summarized in the triple-recommendation letters FDI.
\end{abstract}

Keywords:FDI, Private Domestic Investment, Public Domestic Investment, Cost-Reducing and Heighten Competition hypothesis, Nigeria.

\section{Introduction}

Since the publication of Schumpeter (1911) on the role of capital in fostering real and sustainable development, the literature has been seismically proliferated with extensive empirical studies carried out, mostly in developing economies, to trace the capital-growth nexus, with much accentuation paid to foreign capital. Partly, these studies have been motivated in order to explain empirically the quest among developing nations in continuously attracting foreign capital into their economies, as this form of capital has been deduced as an engine and a vital catalyst of economic growth and development. This economic preference for foreign capital is based on the underlying assumption that foreign capital helps to augment domestic investment capital-gap, improves productivity and enhances competition, as well as managerial and technology spillovers in the host country.

The world economy has experienced soaring foreign direct investment (hereafter FDI) flows since the early 1980s. In spite its vicissitudes and asymmetrical distribution, FDI has grown faster than either world trade or world output. During 1980-98, global FDI outflows increased at an average rate of about 13 percent a year, compared with average rates of 7 percent both for world exports of goods and nonfactor services and for world GDP at current prices (Padma and Karl: 1999).

Figure 1: Trend Pattern on Growth Rate of World Total FDI Stock and Export

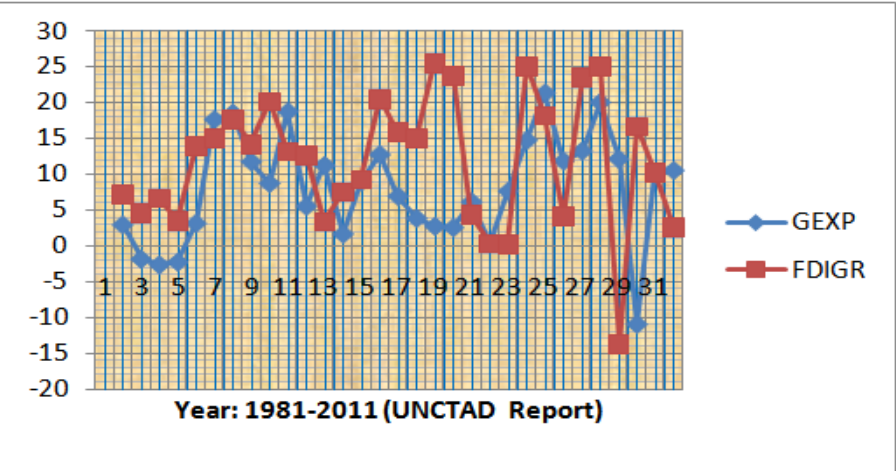


This increase in FDI, according to economic historians, is attributed to structural liberalization of domestic economy and financial markets, as well as the change of attitude by most national governments from hostility to FDI-friendly dispositions (Anyanwu: 2011).

However, despite the increasing flow of FDI, its distribution has been uneven. Most of the world FDI has been concentrated in industrially developed countries, with developing countries receiving, relatively, a small portion of total FDI as a group (See UNCTAD World Investment Report). Decomposing developing economies into regional blocs, the asymmetric distribution of FDI is more glaring and loud. FDI among developing nations skewed in favor of Asia, while Africa's share remains relatively insignificant. Asia has experienced the fastest rate of growth in FDI flows, with China gulping one fifth of the continent's FDI flows, approximately 30 percent of foreign direct investment going to developing economies, and 12 percent of world total FDI flows (UNCTAD report, 2010).

Table 1: FDI Inflows to Developing Bloc (Percentage of world total in US \$)

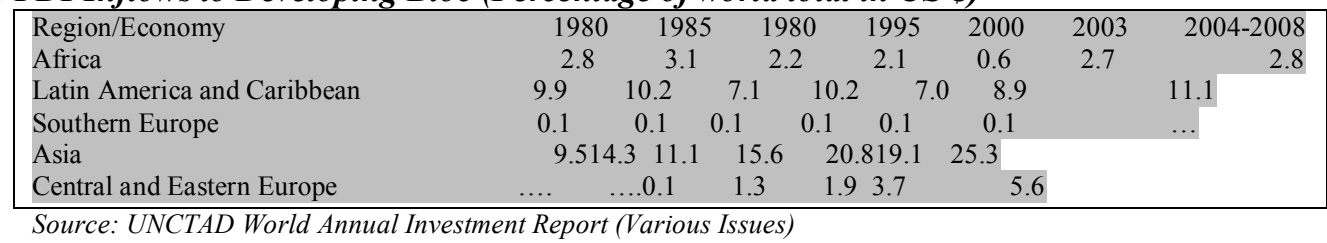

Table 1 reveals FDI inflows to developing countries as a percentage of world total on aggregate basis. It reveals that Asia and Latin America regions have been successful in attracting the bulk of foreign direct investments flowing to developing bloc, with Southern Europe being the most disadvantaged.

Africa, sub-Saharan Africa (SSA) in particular, has not particularly benefited from the FDI boom. For most of the time since 1970, FDI flows into Africa have increased only modestly (Adeolu, 2007). In spite this meager windfall, some countries in Africa have been the continent's FDI hot spots and have been successful in attracting FDI based on their comparative advantages, mostly the existence of natural resources and market size. This assertion is in tandem with UNCTAD world investment report data (2006) that reveals that the three largest recipients of FDI are South Africa, Nigeria and Angola, which are endowed with natural resources and account for about 30 percent of the continent's FDI inflow.

FDI flow into Nigeria is perceptibly small compared to most economies in Asia, Europe and America. However, in absolute terms, FDI constitutes a significant share of total investment in the country, with illuminating and excellent scores in the nation's energy, manufacturing, and telecommunication sectors. The country accounts for above 70 percent of foreign direct investment into West African sub-regional and receive, on the average, 11 percent of the Africa's total (UNCTAD, 2006). During the first decade of independence, conscious and deliberate strides were not taken to encourage FDI flows. The import substitution strategy (ISS) and indigenization policy adopted in the 60s and early 70s was FDI inhibiting. These policies restricted foreign participation and dictated sectorial allocation of foreign capital and Greenfield ownership in the economy. These policies were sustained by the windfall of oil revenues, thus investment capital (private and public) was believed to be in excess.

Due to the over reliance of the Nigerian economy on oil, the oil market crash of late 70s led to serious shortage of investment capital, with most of the social investment projects of the third and fourth development plans (1975-1985) abandoned. As pointed out by Anyanwu (2011), this malady influenced the Nigerian government to embark on a swift and extensive search for alternative capital, and a scheme of policy-attractingFDI was implemented, such as liberalizing the financial market and further opening up of the economy by the implementing the SAP thrusts, privatization and abandoning the ISS policy, granting tax relief and concessions of local material development. Also, FDI-inducing institutions were established to sustain its continuous flows and boast foreign investors' confidence in the economy. These include Export Processing zones (1991); the Nigerian Export-Import Bank (1991); the Industrial Development Coordinating Committee (IDDC, 1988), which was replaced by the Nigerian Investment Promotion Commission in 1995 (Anyanwu, 2011). The impact of these policies and programmes collectively was overwhelming. FDI inflows more than quadrupled, increasing from $\$ 2.3$ million in 1975 to $\$ 10.4$ million in 1990, and thereafter, FDI inflows have been rosy and increasing at a modest rate. Presently, the country is the most favored destination of foreign capital in Africa, gulping more than $15 \%$ of total FDI flows into the continent (UNCTAD, 2012).

Given the plausibility of the theoretically potential gains emanating from FDI, world economies, developing economies in particular, have been at a logger-heads in trying to attract a significant portion of global FDI flows, hence making the market for FDI highly competitive. This is in cognizance of the fact that FDI should be attracted first, after which its gains could be tapped. The body of empirical evidence, however, reveals that FDI flows to a particular country is influenced by a gamut of determining factors, without which a country would be unsuccessful. Although with unanimity lacking in the empirical literature on which factor 
significantly influencing FDI flows (this is attributed to varying area specifics), most determinants of FDI flows have been empirically explored(Anyanwu, 2011; Obida and Abu, 2010; Dinda, 2009; Asiedu, 2005; Laura, 2003; Padma et al 1999; Borensztein, 1998; Anyanwu 1998). However, in the literature, less prominence has been given to the effect of domestic investment, especially in Nigeria. RecallingDe-Mello (1999), he finds that the extent to which FDI is growth-enhancing depends on the degree of complementarity or substitution between FDI and domestic investment. Buttressing this, Ekpo (1997)observed that public investment directly influences private investment. As such the public (government) should invest in infrastructures which give an enabling environment for private investors; consequently, helping in attracting foreign direct investment to Nigeria.

Nigerian government has invested a lot in trying to create an enabling, least-cost environment that promotes investment opportunities through infrastructure development, market-friendly policies, and establishment of complementary ventures to augment local resources needed by firms; but public investment only constitutes part of total investment. Most studies on domestic investment as a determinant of FDI look at it as composite variable, without decomposing domestic investment into its constituents-private and public, thus knowing the individual influence on FDI. Similar studies have been carried out on FDI and private domestic investment. Most of these studies are summarized under a title like the impact of FDI on domestic firms or entrepreneur formation. These studies implicitly assumed that FDI granger causes domestic firms' productivity. However, there could bi-causality between the variables. This study deviates from earlier studies in Nigeria (Ekpo, 1997; Anyanwu, 1998; Ndikumana and Verick, 2008)by empirically exploring the individual effect of domestic investment on FDI flows through dichotomizing it into its parts- private and public investment.

The rest of this paper is divided into five sections. Following the introduction, section II reviews related literature on the topic. Section III set out the research methodology, while Section IV presents the empirical results. Section V rounds it up with the conclusion and recommendations.

\section{Literature Review}

One of the most extensive research areas in international finance and capital movement is FDI-related. Scholarly and empirical studies have focused majorly on FDI determinants and FDI-growth nexus. The later has been extensively studied narrowly, ranging from panel survey to country specifics studies, i.e., precisely tracing the plausible channels through which FDI impact on the host country. Anyanwu (2011) while reviewing the literature observed that mixed opinions exist among veteran researchers on the impact of FDI on growth; FDI could be growth-inducing (or growth-inhibiting) through crowding in (or crowding out) of domestic investment and domestic entrepreneurship. Also, there has not been a unanimous consensus among empirical studies on the precision of FDI determinants. However, researchers espoused that country or regional specifics influence FDI inflows.

Our study is among the few in the literature on the effect of domestic investment on FDI. Its peculiarity is it ingenious practice of decomposing domestic investment into its parts. The purport of this method is overwhelming; it shows if these components of domestic investment are FDI-attracting.

\section{Concept of Foreign Direct Investment}

Foreign direct investment has been given different definitions by academic scholars and institutions, but the bottom line remains the same. The United States Department of Commerce defines FDI to include all 'foreign business organizations in which a U.S citizen, organization or affiliated group owns an interest of ten (10) percent or more'. The United Nations defines foreign direct investment as 'investment in enterprise located in one country and effectively being controlled by residents of another country'. This definition does not only consider FDI as being mere investment, it also stresses on the status of corporate control.

World Bank (1996) sees FDI as 'investment made to acquire a lasting management interest (normally ten percent of the voting stock) in a business enterprise operating in a country other than that of the investor defined according to residency'.In line with this, the United Nations Conference on Trade Agreement and Development (UNCTAD) defines FDI as 'an investment involving management control of a resident entity in one economy by an enterprise resident in another country'. As further classified by Organization of Economic Cooperation and Development (OECD, 1992), FDI refers to a situation in which a single investor controls less than $10 \%$ percent or more of the ordinary or voting power with a view to having an effective voice in the management of the organization.

Corollary, Todaro and Smith (2009)defines FDI simply as 'a corporation that conducts and controls productive activities in more than one country'. Buttressing this, Nobel laureate Paul Krugman defines FDI as 'international capital flows in which a firm in one country creates or expands a subsidiary in another'. Also, in his own words, Rutherford (1992) defines FDI as 'investment in businesses of another country which often takes the form of setting up a local production facilities or the purchase of existing businesses.

A lead driver of foreign direct investments, especially in LDCs, is multinational corporations (MNCs). MNCs are enterprises with headquarters mostly in developed countries and also operate in other countries, both 
developed and developing with net sales of \$100million dollars to several thousand million dollars (Jhingan, 2007). FDI is the distinctive feature of MNC; hence a theory of FDI is also a theory of multinational enterprise as an actor in the world economy. Based on this proposition, FDI is not simply an international transfer of capital but also the extension of an enterprise from its home country into a foreign-host country.

\section{Rationale for Attracting Foreign Direct Investment}

Todaro and Smith (2009:719) proffer a comprehensive rationale for FDI, which they tagged traditional economic argument in support of foreign private investment. To them, the main reasons for attracting FDI inflows are to fill the savings, foreign exchange, revenue, and management gaps. The first and most often cited rationale of FDI to national development (i.e., when development is defined in terms of GDP growth rate) is its role in filling the resource gap between targeted or desired investment and locally mobilized savings. When the domestic resources (savings) fall short relative to the potential investment, FDI is seen as an alternative to fill-up that gap; second, it contributes to filling the gap between targeted foreign exchange requirements and those derived from net export earnings plus net foreign aid. This is the so-called foreign exchange or trade gap. An inflow of foreign capital cannot only alleviate part or the entire deficit on the balance of payment current account but also function to remove that deficit over time if the foreign-owned enterprise can generate a net positive flow of export earnings.

Furthermore, FDI augment the revenue of the host country. By taxing MNCs profit, the host nation is thought to be better able to mobilize public financial resources for development projects. Also, foreign investments bring with them advanced management, entrepreneurship, technology and skills that can be transferred to their local counterparts by means of training programs and the process of learning by doing.In addition, FDI is said be socially desirable in LDCs because it leads to a net increase in capital formulation, output, and employment. However, it is pertinent to know that this rationale differ from country to country. This explains why some countries are making concert effort to accelerate economic growth by encouraging inflows of foreign capital while others are indifferent.

\section{Nigerian Domestic Investment Profile}

Investment is the monetary outlay on real asset such as factory plants, inventories, real estate, also including the provision of socially desirable assets like education, transportation, communication, and healthrelated utilities, among others. Any asset that does not contribute towards the provision or production of goods and services is, however, not referred to as an investment.Total investment in an economy is cumulatively the sum of both domestic and foreign investible capital:

$$
I_{t}=I_{d}+I_{f}
$$

Where $\boldsymbol{I}_{t}, \boldsymbol{I}_{\boldsymbol{d}}$, and $\boldsymbol{I}_{f}$ are total, domestic, and foreign investment, respectively.

Domestic investment, which comprises of private and public investment, is a vital component of total investment. For most economies, especially developed countries, the share of domestic investment is significantly large, sometimes higher than foreign capital; this is, however, a visibly opposing feature for most developing economies, where internally sourced capital is insufficient and inhibits targeted investment. For these economies, Nigeria in particular, public and private investment as a percentage of the GDP is significantly small and her economy relies heavily on foreign capital.

During the first decade following independence, public investment as a percentage of GDP in Nigeria was, on the average, below 5 percent. Most social capital projects were mainly concentrated in urban areas, while the rural areas were wholly disconnected from the investment web. Following the discovery of oil in huge reserves in the Niger Delta and backed with foreign preference for Nigerian sweet crude, government revenue generation received a boast, and the capital expenditure of the government soared. Empirically, public investment (as \% of GDP) increased by 400 percent, from a staggering value of 3.6 in 1970 to 14.9 in 1975 . This impressive score remained so, maintaining an average of 15 percent to the GDP until the oil market crashed in the late 70s, which resulted to falling revenues and declining public investment by the government. Precisely, public investment plummeted from 13 percent to 9 percent in 1982 and 83, respectively. Though it recorded a value of 12.3 percent in 1986, resulting from the augmentation of domestic revenue by the IMF and World Bank, public investment has stayed below 10 percent thereafter, except for an anticipated rise fuelled by the electoral process in 1998 and 1999. The shabbily rates of public investment in the mid-2000s' could be linked to the global financial crisis of the period that affected government revenue earnings from crude oil export.

Gross capital formation which measures total investment undertaken by private individuals in the domestic economy complements public investment. Similarly, private investment in Nigeria has trended same pattern with public sector investment. In the late 70's and 80's, private investment as a percentage of GDP was averaging 25 percent annually, and during this period, higher than public investment. However, since 1995, private domestic investment has been on a decline, averaging below 10 percent annually. The figure below reveals the trend analysis of private and domestic investment as percentages of the GDP. 


\section{Figure 2: Trend of Public and Private Investment as a \% of GDP (1970-2008)}

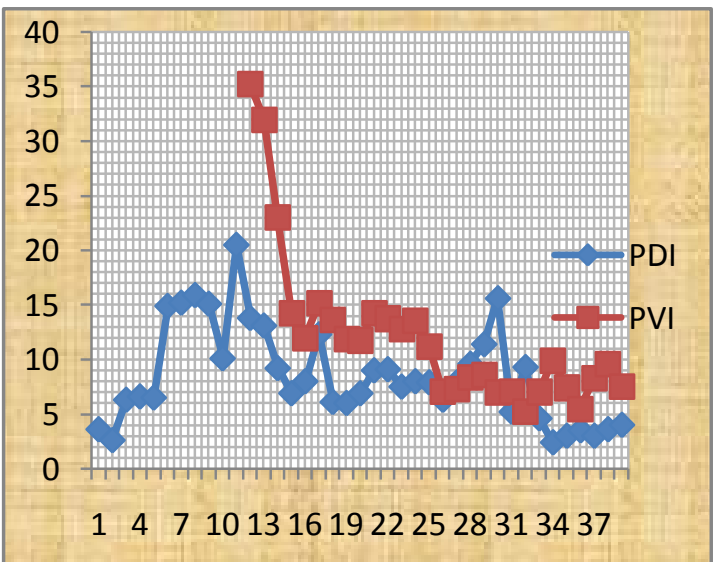

$\boldsymbol{P D I}$ and $\boldsymbol{P V I}$ represent private and public domestic investment, respectively. Data on Gross Capital formation started from 1980, thus obtaining data for other years proved difficult at the moment. It could be observed that both $\boldsymbol{P V I}$ and $\boldsymbol{P D I}$ trended similarly during the studied period.

Source: Authors' Computation: data sourced from CBN bulletin (2009)

The poor trend of private investment in Nigeria is linked to unfavorable investment clime occasioned periodically by dysfunctional infrastructural base, insecurity, institutional failure, and unsupportive economic policies. The collective effect of these irregularities is an increase in the cost of doing business in Nigeria, which hampers firms' formation, shutting down of existing ones, and the repatriation of foreign capital.

\section{Theories Linking FDI with Domestic Investment}

A body of empirical evidence suggests a strong positive relationship between foreign investment and domestic investment. Ndikumana and Verick (2008)espoused that this relationship is bi-directional. They further assert that a high private domestic investment is a signal for high returns to capital, while adequate public infrastructure (through high public investment) reduces the cost of doing business, which raises the marginal return to FDI. Hence, high domestic investment helps in attracting FDI.

As observed from table 1 above, world FDI flows have been lopsided, with developed bloc accumulating to themselves a significant share of it. Recalling Anyanwu (2011), this massive flow of FDI to the first world do not occur by chance, rather, it occurs by them having the absorptive capacities to attract FDI. This is what the literature calls the determinants of FDI. A close inspection highlights the magnificent public utilities development ranging from state-of-the-art transportation, energy and communication facilities in developed countries, which is attributed to the massive public investment in those sectors. World evidence reveals that China is becoming the world best destination of FDI flows due to its investment-friendly clime, backed by huge domestic investment, low wage, and transition to a market economy (Wei, 2008). Other developing countries that have benefited by attracting significant FDI flows through upgrading their public utilities are the Asian Tigers, such as Malaysia and Singapore.

The effect of domestic investment on FDI flows could be understood through what we call Cost reducing and Heighten competition hypothesis. Here, we postulate that domestic investment mitigates operation cost and strengthens competition. Juxtaposing two national economies with relative differences in domestic investments, it is plausibly reasonable to argue that the country with well-developed public utilities would experience reduced operational cost by firms operating in it relative to the other. These facilities in form of social infrastructures aid firms in the production and distribution processes. In the absence of these production aids, firms have the alternative to providing for themselves, thus increasing the cost of doing business and lack of entrepreneur incentives. Given the unviability of business engagements in this economy, foreign investors and capital are less attracted, vice versa. This relationship is strongly correlated with public domestic investment.

However, the effect of private domestic investment on FDI flows is more intricate. Private domestic investment could encourage or discourage FDI flows in an economy. It depends on the specific relationship between private and foreign firms as well as how developed the domestic private sector is. In a situation where most private firms in a sector is operating in utmost technical and economic efficiency and have high-rated international standing, the potentials of market competition is almost exhausted, foreign firms view such sector as unprofitable, thus driving them away. But in situation of less competition among private firms, FDI is attracted. A dramatic example is the aviation sector in the USA, where Air Bus dominates the market for 
commercial airplanes production. Other firms, say, Boeing, in the same line of trade has been discouraged in setting-up plant in USA because of the hotly competition from Air Bus.

In a different lens, foreign capital flows into a domestic economy where substantial private investment has been made in the downstream sector. This is referred to as the Backward LinkageEffect between FDI and private investment. Because foreign investments are long-term capital projects, foreign firms take into consideration local sourcing of materials before siting their plants. If adequate investment is not been made in the downstream sector, and foreign firms are supposed to import almost every component of their production process, it would be worthwhile for them to set-up production plant in home economy and export the finished products to them. This scenario- absence of a developed downstream sector- is FDI-inhibiting.

\section{Historical Facts: Stylized Facts on FDI Flows and Nigerian Economy}

Right from the colonial days, the Nigerian economy has been hijacked by external forces, making it rather difficult for the country to achieve economic independence and self-sustaining social progress. British capital, in particular, and western capital, in general, has been enabled to find in the country a hospitable clime. The ideology of free enterprise imposed on the country during the colonial era and adopted thereafter in the post-independence period played a critical role in integratingthe economy into global capitalism, making it possible for further inflow of foreign capital into the country.Prior to her independence from British colonial rule, FDI in the Nigerian economy was largely dominated by investment in the non-oil sector. The basis for foreign investment was imperial expansion through colonization or establishment of oversea subsidiaries of state trading companies (Edeogu, 2009). Nigeria played host to couple of foreign companies like the United Africa Company (UAC), Leventis, etc., which were involved in the purchase and export of cash crops. However, the country's independence in 1960 was to change a lot of things politically, socially and economically. Nigeria took her future in her hands, and so various policies were adopted to ensure the young country's survival. The first twelve (12) years of independence saw the country's economy being sustained by export earnings from agriculture, with a vast array of cash and food crops.

Then, in the mid-seventies (70s) came the discovery of oil, which marked a trend reversal and the beginning of a structural shift and the attendant sectorial imbalance of the Nigerian economy in favor of the oil sector (Edeogu, 2009). Major investments started coming into the country in order to tap from the huge oil deposits. There were influx of oil and construction multinationals from Britain, France, USA, Italy, Germany, etc. By 1972, this reversal in trend was evident with the share of foreign investments in the oil sector rising to $66 \%$ while that of non-oil sector declined to $34 \%$. By 1974, the crucial role of the oil sectors as the main stay of the Nigerian economy had been thoroughly established. In that year, the oil sector cornered a share of $97.5 \%$ of total FDI while that of the non-oil sector stood at $2.50 \%(C B N, 2005)$. This upward swing is traced to the astronomical increase in crude oil prices in the aftermath of the Arab-Israeli war in 1973. This sectorial imbalance has made the country a monoculture economy.

The adoption of imports substitution policy, carefully dictated under private sector-led growth, compelled the multinational corporation to establish manufacturing plants in the country; however, this policy didn't go down well. The economic crisis in the early 1980's and the realization of the fact that the erstwhile import substitution strategy was a failure coupled with the positive impact of FDI in some countries, especially the South-East Asia countries, forced the government to revert back to the Pre - 1970 industrial policies which gave considerable attention to attracting FDI (Odusola, 2002). In mid-1986, the Structural Adjustment Programme (SAP) was designed to address the gross distortions and imbalance in the economy. Unfortunately, the implementation of the laudable SAP policy served to encourage trading and speculative activities rather than diversifying the economy from a monoculture economy, thus encouraging FDI inflows to other sectors.

The inauguration of a democratic government in May 1999 raised hopes of redressing the ecological, social, and economic damages of the military rule. The country began a gradual progression towards creating a political and social environment, supportive of corporate social responsibility and ultimately sustainable development (Okomoh, 2004). As a matter of fact, Nigeria witnessed greater FDI inflow between 1999 and 2001. Another factor responsible for the phenomenal increase in foreign direct investment apart from economic policies is the legal regime and its related institutions required for the creation of a market economy and suitable investment clime were priority public policy agenda of the new civilian regime.

Empirically, in 2001, cumulative foreign private investment in Nigeria was $\$ 160,882.2 \mathrm{~m}$, representing an increase of $2.1 \%$ over the level in the preceding year. Companies from Western Europe (excluding UK) maintained their lead in terms of shares, which, however, declined slightly to $52.9 \%$ in 2001 , from $54.2 \%$ and $53.6 \%$ in 1999 and 2000 , respectively. The shares of companies from UK increased slightly from $20.8 \%, 22.0 \%$, $22.1 \%, 23.4 \%$, in $2000,2001,2002$, and 2003 , respectively, fell to $19.7 \%$ in 2004 and regained its strength subsequently. Also, the shares of companies from United States and other unspecified counties increased from $13.0 \%$ and 11.3 in 1999 to $14.2 \%$ and $12.6 \%$ in 2003 , respectively. However, in 2008, FDI from USA fell to $12.8 \%$ due to the financial crisis $(C B N, 2009)$.Presently, there has been an upsurge in FDI flows from Asia, with 
China and India as the lead drivers. Tremendous growth in FDI flows has been registered in the telecommunication sector due to the Global System of Mobile communication (GSM) pact signed in 2001 by Obasanjo's administration. The Table below reveals FDI flows in Nigeria.

Table 2: FDI in Nigeria (Mean values and percentage to the GDP: 1975-2009)

\begin{tabular}{lcc}
\hline Year & Nominal FDI(Nillion) & FDI as \% of the GDP \\
$1975-1979$ & 2634.8 & 8.9 \\
$1980-1984$ & 5025.7 & 4.5 \\
$1985-1989$ & 9670 & 4.6 \\
$1990-1994$ & 36138.8 & 5.8 \\
$1995-1999$ & 73709 & 5.1 \\
$2000-2004$ & 182656.2 & 2.7 \\
$2005-2009$ & 486226.6 & 1.9 \\
\hline Source: Authors computation. Data sourced from $C B N$ Statistical Bulletin (2009).
\end{tabular}

From the table, despite increases in nominal FDI flows, its relative share to gross domestic product is on the decline.

\section{Sectoral Analysis of FDI among Sectors}

Manufacturing and the extractive sectors have been successful in attracting foreign direct investment to Nigeria. This stems basically from the fact that Nigeria is endowed with solid and mineral resources as well as a vibrant, large market size. Using the cumulative levels of foreign investments within the specified period, private investment flows into the mining and quarrying sector was $959.8 \mathrm{~m}$ in 1975 , which represented $41.9 \%$ of the total distribution of FDI. However, in late $70 \mathrm{~s}$ and through the $80 \mathrm{~s}$, its total distribution fell. For example, in 1980-1984 and 1985-1989, it was 14.1 and 19.3 percent, respectively. It rose astronomically in 1995-1999, with a $43.5 \%$ share before decline to 36.6 and 24.5 in the subsequent periods.

Further, the manufacturing and processing sector witnessed a steady flow of FDI into its sector in terms of its cumulative total. But relative to its percentage distribution of total, there have been fluctuations in this sector. It recorded its highest share in 1990-1994 with a 43\% share. The Agriculture, building and construction sectors remained the list attractive hosts of FDI in Nigeria. With FDI share of $2.5 \%$ and 6.4 in 1975-1979, in $2005-2009$ it was $0.3 \%$ and $2.2 \%$, respectively.

The, trading and business services sector has lost its attractiveness to foreign investors, as it is being dominated by indigenous capital and investors. It used to be among the most attractive sector by investors in the prior before independence and the first decade of 1960, where such trading giants like UAC, John Holt, Leventis, etc., were chiefly trading firms in the areas of manufactured products produced in more developed countries as well as exporters of agricultural produce out of Nigeria. It had a share of 32.6 in 1985-1989 period, however, it could only boost of less than 10 percent in total FDI flows.

Table 3: Sectoral Distribution (percentage) of FDI among Sectors (1975-2010)

\begin{tabular}{|c|c|c|c|c|c|c|c|}
\hline \multirow{2}{*}{$\begin{array}{l}\text { Year } \\
\text { unicationtr } \\
1975-1979 \\
\end{array}$} & \multicolumn{2}{|c|}{$\begin{array}{l}\text { Mining \&Manu- } \\
\text { Quarrying facturing } \\
\text { tion }\end{array}$} & \multicolumn{2}{|c|}{ 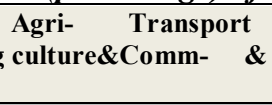 } & $\begin{array}{l}\text { Building } \\
\text { Cons- }\end{array}$ & \multicolumn{2}{|c|}{$\begin{array}{l}\text { Trading \&Others } \\
\text { lsiness }\end{array}$} \\
\hline & 30.8 & 32.4 & 2.5 & 1.4 & 6.4 & 20.4 & 6.1 \\
\hline 1980-1984 & 14.1 & 38.3 & 2.6 & 1.4 & 7.9 & 29.2 & 6.5 \\
\hline $1985-1989$ & 19.3 & 35.3 & 1.4 & 1.1 & 5.1 & 32.6 & 5.2 \\
\hline 1990-1994 & 22.9 & 43.7 & 2.3 & 1.7 & 5.7 & 8.3 & 15.4 \\
\hline 1995-1999 & 43.5 & 23.6 & 0.9 & 0.4 & 1.8 & 4.5 & 25.3 \\
\hline 2000-2004 & 36.6 & 27.8 & 0.7 & 1.1 & 2.5 & 7.6 & 26 \\
\hline 2005-2009 & 24.5 & 32.8 & 0.3 & 1.9 & 2.2 & 8.5 & 29 \\
\hline
\end{tabular}

\section{FDI Inflows and Domestic Investment Relation in Nigeria}

Nigeria is a small- relative to share of world output- and an open economy, with a friendly disposition and well-patterned diplomatic manner to the outside world. Since 1986, the country has become a hospitable clime for foreign investors, for plausible reasons that have been verified empirically in the literature (for an exegesis on the determinant of FDI see Ekpo, 1997; Anyanwu, 1998). As espoused earlier on FDI-Domestic Investment (DI) relationship, especially on a unidirectional flow going from DI, there is a dearth of empirical studies, but this does not connote that FDI is unconnected to DI; the verity is that DI influences FDI in a gamut of ways. As noted by Anyanwu (1998), in addition to other variables in his model, he adduced that domestic investment serves as a very important factor influencing FDI positively into Nigeria, although he was not specific on which of the components of DI has the higher margin.

A closer inspection of FDI inflows and DI in Nigeria, in nominal terms, reveals similar trend-like pattern. This suggests, intuitively, positivism between the variables. The graph below buttresses this claim. 
From the figure, the nominal values of FDI, private and public DI all exhibit an upward trend through time. Private domestic investment (PVI) is seen to be above PDI and FDI, illuminating the fact that private domestic investment dominate the market of domestic investment capital.

However, in spite the congruity in trend pattern, some researcher still questions such statistically. Olatunji (2001) in another development argued that despite government efforts to provide incentives private investors, many investors are still adamant to come to Nigeria. He noted that this might not be unconnected with the lingering problems that still persist on ground, and foremost on these causes is the shabbily domestic investment on infrastructure facilities.

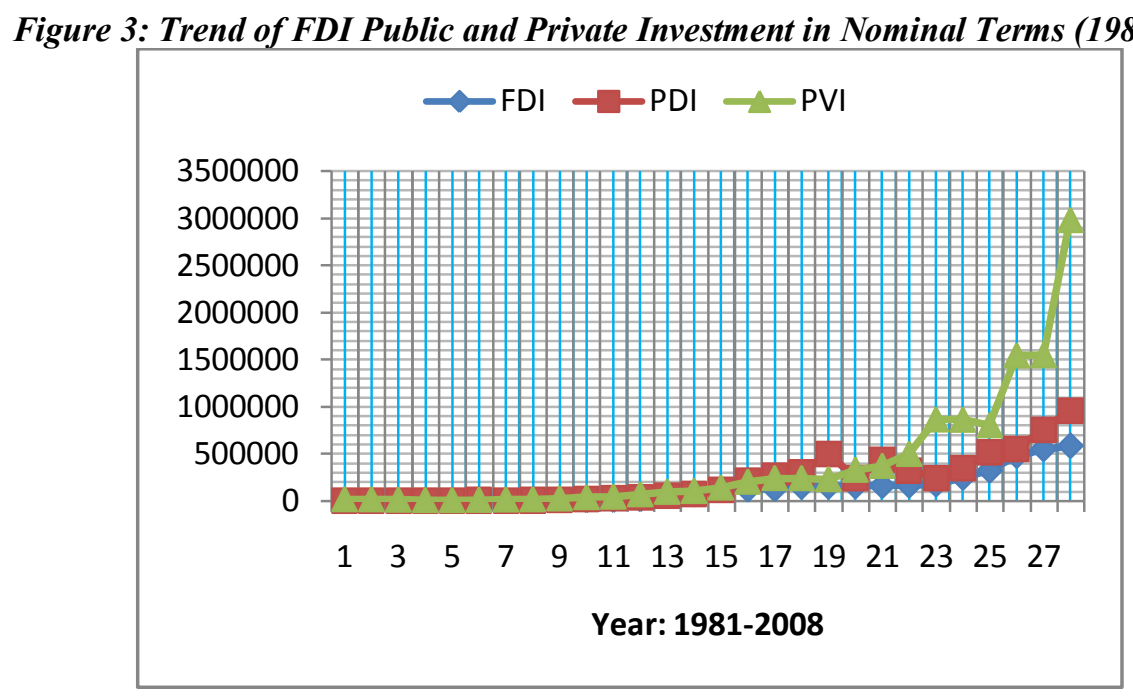

From figure 3, the graphs of FDI, PDI and PVI trended upwards through time, establishing what seems somewhat as a positive relationship among them, at least graphically.

\section{Empirical Literature}

The intense drive by developing countries to attract FDI into their economies has generated much empirical studies to evaluate the rationale behind FDI and explore the absorptive capacities (determinants of FDI) that must be fulfilled by the host economy. However, most of the earlier works on determinants of FDI has made little or no attention to domestic investment. The few studies that touched on it did so in passing or either looked at it as a unidirectional flow going from FDI to domestic investment.Anyanwu (1998) identified change in domestic investment, change in domestic output or market size, indigenization policy and change in openness of the economy as major determinants of FDI. He further noted that the abrogation of the indigenization policy in 1995 encouraged FDI inflow into Nigeria and that effort must be made to raise the nation's economic growth so as to be able to attract more FDI. Also, Razin et al (2003) find that the gains from FDI are reflected in a moreefficient size of the stock of domestic capital and its allocation across firms.

Uwubanmwen and Ajao (2012), adopting a Vector Error correction Model (VECM), examines the determinants and impacts of FDI in Nigeria. His findings suggest that public investment (measured by government size in the economy) has a positive but insignificant influence on FDI. Moreover, in a similar study, Eli et al (2006) investigated the determinants of FDI and economic growth in the West Africa Monetary Zone. Using a simultaneous regression methodology to obtain estimates on public investment, political instability, inflation, real interest rate, etc., found, among others, that public investment has a positive and significant relationship with foreign direct investment.

Unraveling the developmental impact of foreign investment in sub-Sahara African economies, Ndikumana et al (2008), estimating with Error Correction Model on a panel survey of Sub-Saharan Africa economies, explore the linkages between FDI and domestic investment. The results suggest that firstly, FDI crowds in domestic investment, and secondly, countries will gain much from measures aimed at improving the domestic investment climate.

Furthermore, Ahmad (2010) analyzed the relationship between foreign direct investmentDomestic Investment and Economic Growth for Pakistan. The main findings of the paper are as follows: a) There is a bidirectional causality between FDI and domestic investment, domestic investment andeconomic growth;unidirectional causality between FDI and economic growth in the long run. b) High degree of positive correlation found between FDI, domestic investment and economic growth. Vetting on this is Ekpo(1997), on a study of FDI in Nigeria. He observed that public investment directly influences private investment, as such the public 
(government) should invest in infrastructures which give an enabling environment for private investors; consequently attracting foreign direct investment to Nigeria.

A comprehensive study by Bosworth and Collins (1999) provides evidence concerning the effect of capital inflows on domestic investment for fifty-eight developing countries during 1978-95. The authors distinguish among three types of inflows: FDI, portfolio investment, and other financial flows (primarily bank loans). They uncover that an increase of a dollar in capital inflows is associated with an increase in domestic investment of about fifty cents. This result, however, masks significant differences among different types of inflows: foreign direct investment appears to bring about close to a one-for-one increase in domestic investment; there is virtually no discernible relationship between portfolio inflows and domestic investment (little or no impact); and the impact of loans falls between those of the other two. These results hold both for the fifty-eightcountry sample and for a subset of eighteen emerging markets.

Most of other studies on theoretical determinants of FDI excluded domestic investment from the list (see Adeolu, 2007, Asiedu, 2005). Hence, this study contributes to the existing literature by investigating the individual effect of private and domestic investment on FDI flows in Nigeria. To the best of our knowledge, this is the first of its kind in the country. In spite this dearth of empirical studies on the effect of domestic investment on economic growth in Nigeria, both the theoretical and empirical literature seems near-unanimous in their conviction that domestic investment, public investment in particular, influences positively FDI flows. Buttressing this, Ahmad (2010)suggests several ways through which domestic investment affects FDI. One obvious channel is through public investment in physical and human infrastructure. The better the infrastructure, the more profitable FDI would be.

\section{The Empirical Model And Methodology}

Building on the cost reducing and heighten competition hypothesis, we develop a multiple econometric model to capture the effect of public and private domestic investment on FDI flows. Also, our model includes other factors explored in the literature as major determinants of FDI. Following Anyanwu (2011) and given the country specifics, we include market size, stock of natural resources, trade openness, and human capital. Thus, the Model is:

$$
F D I_{t}=\alpha+\beta X_{t}+e_{t} \ldots \ldots \ldots \ldots . . . .1
$$

Where $\boldsymbol{F D I}$ represents foreign direct investment; $\boldsymbol{X}_{\boldsymbol{t}}$ are the observable variables representing factors affecting $\boldsymbol{F D I}$ in time series form, $\boldsymbol{\alpha}$ and $\boldsymbol{\beta}$ are parameters to be estimated, and $\boldsymbol{e}_{\boldsymbol{t}}$ is a random error term with a mean of zero. Expanding the RHS of equation 1, we have:

$$
F D I_{t}=f(P D I, P V I, M A S, N A T, H U M, O P N) \ldots \ldots \ldots \ldots \ldots . . .2
$$

Mathematically, the model is specified as:

$$
\mathrm{FDI}_{t}=\alpha+\beta_{1} P D I_{t}+\beta_{2} P V I_{t}+\beta_{3} M A S_{t}+\beta_{4} N A T_{t}+\beta_{4} H U M_{t}+\beta_{5} O P N_{t} \ldots \ldots \ldots . . .3
$$

To account for random effect and omitted explanatory variables that would have impact on the regressand, equation 3 is rejiggered as thus:

$$
F D I_{t}=\alpha+\beta_{1} P D I_{t}+\beta_{2} P V I_{t}+\beta_{3} M A S_{t}+\beta_{4} N A T_{t}+\beta_{4} H U M_{t}+\beta_{5} O P N_{t}+e_{t} \ldots \ldots \ldots \ldots . .4
$$

The added variables PDI, PVI, MAS, NAT, HUM, and $\boldsymbol{O P N}$ represent public and private domestic investment, market size, stock of natural resources, human capital, and trade openness, respectively, $\beta_{1}-\beta_{6}$ are the slope coefficients of the regressors, $\alpha$ represents the vertical intercept, $\varepsilon$ the stochastic residual term, which is normally distributed.

\section{Econometric Methodology}

We apply the ordinary least squares (OLS) to estimate equation 4. The stages towards deriving the OLS include first testing for stationarity using the Augmented Dickey Fuller test (ADF), thus:

$$
\Delta y_{t}=\alpha_{0}+\gamma y_{t-1}+\Sigma \beta_{t} \Delta y_{t-1}+\varepsilon_{t}
$$

The ADF above is that of constant and no trend model. Where $\boldsymbol{\Delta} \boldsymbol{y}_{\boldsymbol{t}}=\boldsymbol{y}_{t}-\boldsymbol{y}_{t-1}$ is the first difference of the series $\boldsymbol{y}_{t} ; \boldsymbol{\Delta} \boldsymbol{y}_{t-1}=\left(\boldsymbol{y}_{t-1}-\boldsymbol{y}_{t-2}\right)$ is the firstdifference of $\boldsymbol{y}_{t-1}$, etc.; $\boldsymbol{\alpha}, \boldsymbol{\beta}$ and, $\boldsymbol{\gamma}$ are parameters to be estimated, and $\boldsymbol{\varepsilon}$ is a stochastic disturbance term. Next, we test for the long-run relationship among the variables in equ. 4 . We adopt the Johansen Cointegration Tests to evaluate for this relationship.

\section{Data Source and Scope}

The study on the effect of domestic investment on FDI flows is an area specific investigation, with Nigeria being the case study. Annual data covering four decade(1970-2009) were used for this study. Data 
reflecting proxies for public and private domestic investment, stock of natural resources, market size were ferret out from the Central Bank of Nigeria (CBN) Statistical Bulletin (various issues); that for human capital and trade openness were got from FOS and Penn world Table, respectively; while data on FDI flows were collected from UNCTAD (various issues).

\section{Empirical Analysis}

Avoiding spuriousness in our regression estimates, the time series properties of our variables were tested for unit root and verifying a long-run relationship among the variable by conducting a test of cointegration. The results of unit root and cointegration tests are presented in Tables 4 and 5 below.

The result of the unit root test confirms that all the variables are integrated at first difference. Though we evaluated the calculated ADF values at 5\% level of significance, the values, after first differencing, were also integrated at other levels of significance.

Table 4: Test of Data Stationarity

$\begin{array}{lcccc}\text { Variables } & \text { ADF } & \text { Critical Values at 5\% } & \begin{array}{c}\text { Order of IntegrationFDI } \\ \text { I(1) }\end{array} \\ \text { PDI } & -2.94368 & & & \text { I(1) } \\ \text { PVI } & -5.20237 & -2.9422 & & \mathrm{I}(1) \\ \text { MAS } & -5.01625 & -2.9422 & \mathrm{I}(1) \\ \text { NAT } & -4.80101 & -2.9422 & \mathrm{I}(1) \\ \text { HUM } & -4.84437 & -2.9422 & \mathrm{I}(1) \\ \text { OPN } & -6.87894 & -2.9422 & \mathrm{I}(1)\end{array}$

Authors' Computation

The synopsis of the Johannsen cointegration test reveals the existence of one (1) cointegrating vector, thus the rejection of the null hypothesis of no cointegration among the variables. Therefore, the explanatory variables are cointegrated and have both short and long run relationships with the dependent variable.

Table 5: Johannsen Cointegration Test

\begin{tabular}{ccccc} 
Eigen value & Likelihood Ratio & 5 percent & $\mathbf{1}$ percent & No. of CE*(s) \\
0.763838 & 144.33 & 124.24 & 133.57 & None** \\
0.614747 & 89.488 & 94.15 & 103.18 & At most One \\
0.490825 & 53.241 & 68.52 & 76.07 & At most Two \\
0.293097 & 27.592 & 47.21 & 54.46 & Atmost Three \\
0.187963 & 14.411 & 29.68 & 35.65 & Atmost Four \\
0.151415 & 6.4998 & 15.41 & 20.04 & At most Five \\
0.006837 & 0.2607 & 3.76 & 6.65 & At most Six \\
\hline$*(* *)$ denotes rejection of the hypothesis at 5\%(1\%) significance level. Likelihood ratio indicates 1 cointegrating \\
equation(s) at 5\% (1\%) significance level *ointegrating equation. Source: Authors computation
\end{tabular}

\section{Model's Result}

The confirmation of the absence of unit-root in the time series data as well as the verification of a cointegrating relationship among the variables constitute an approval for the adoption of an OLS methodologythe methodology is appropriate in the statistical quantification of the variables and would produce non-spurious estimates. Below presents this result.

Table 6: OLS Result

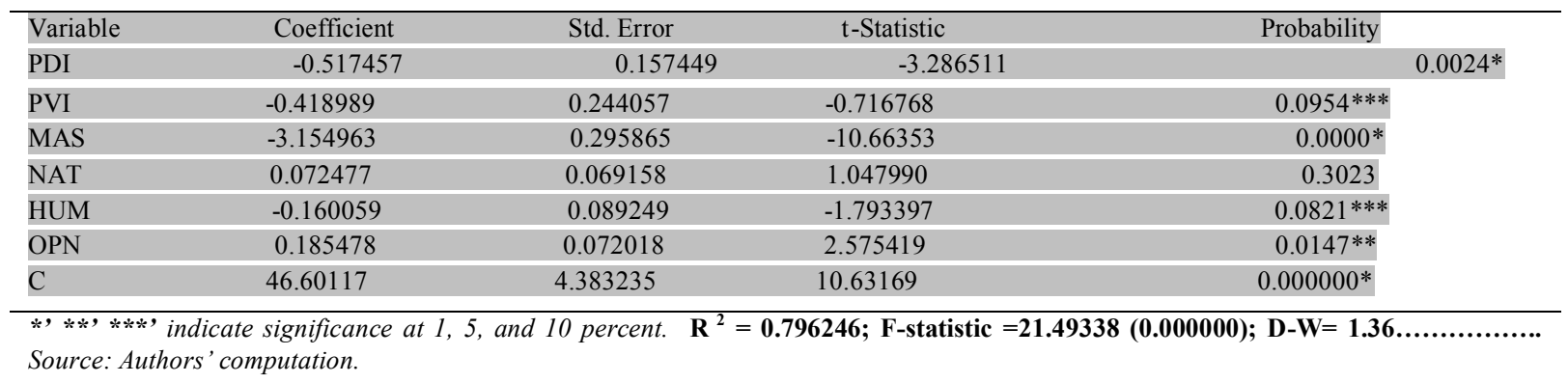

Mathematically,

$F D I=46.6-0.517 P D I-0.419 P V I-3.155 M A S+0.072 N A T-0.160 H U M+0.185 O P N$

From the OLS result, public and private domestic investments have their coefficients negatively signed. This explains an inverse relationship between each of these variables with foreign direct investment flows in 
Nigeria within the study period. The statistical attribute of their coefficients are statistically significant, however. Private domestic investment, within the four decade, is in tandem with the backward linkage effect, while public domestic investment defies a priori test. In econometric parlance, holding other variables in fixity, the slope coefficient of -0.517 for PDI explains this: If public domestic investment increases by a percentage, FDI inflows decline by approximately 51.7 percent. Similarly, if PVI increases by a percentage, FDI declines by 41.9 percent approximately, annually.

Natural resource and economic openness are in akin with theoretical knowledge; their influence on FDI-inflows in Nigeria is positively inclined, with the coefficient of trade openness statistically significant. For human capital and market size, the trend once again is indirect, that is, a negative relationship with FDI-inflows; both variables are statistically significant at $10 \%$ and $1 \%$, respectively. Holding each variable fixed at each successive round systematically, a positive percentage change in natural resource/ or economic openness, increases FDI-inflows by 7.2 / or 18.5 percent; while FDI-inflows decreases by 315/or 16 percent for a percentage increase in market size/or human capital, approximately.

\section{Conclusion And Recommendations}

It has become patent- both in theory and practice -that capital is at the crux of national development, and the consequences of a dearth of this essential resource are near incomprehensible. This adduces for the hotly contest among world economies, developing economies of worthy note, over foreign capital. However, becoming a hot spot is not achievable by fluke; certain criteria must be met by the host economy.

Undeniably, seismic nominal financial expenses have been injected in the Nigerian economy by successive administration and government at all levels towards improving the state of infrastructure and other investment-friendly facilities. However given the shabby result that could not match the proportion of this nominal outlay, it becomes highly imperative to distinguish qualitative expense from quantitative (nominal) expense, as well as divorce the issue of rent-seeking and political consideration in the process. For over five (5) decades the country is yet to achieve the least energy requirement both for industrial and residential use; boast of a state-of-the-art transportation system; impeccable quality and enviable standard in her educational and health sector, inter alia, which are highly needed to drive investment-foreign and domestic private investment included. A classic example is the Nigerian energy sector, a sector at the heart of developmental process and an activator of investment. The epileptic state of the power sector has discouraged the inflow of FDI; inhibit the start-up of most domestic investment, and drove away already established firms to neighboring countries with sufficient energy for a least-cost production. The synergy of all these maladies culminates to the uncompetitive look of the Nigerian investible clime, hence serving as a detour to FDI inflows.

Furthermore, though the premise regarding private domestic investment and FDI is moot in the literature, the scenario surrounding this negative relationship between these variables in Nigeria is more explained practically than in theory. Generically, the Nigerian private sector is still at its embryonic state, partly due to lack of proper inducement from the public and the financial sectors to dispense the much needed capital, and partly from the rudimentary technology and uncultivated habit of entrepreneur development. Recalling what the literature says with respect to FDI-domestic firms nexus: FDI has a positive, backward relationship with domestic firms. If the host economy has a well-developed local material sourcing sector, the presence of a multinational firm in the sector tends to rekindle activities in the sector. Unfortunately, Nigeria is at the opposite end; this sector is not only nascent but also crude and informal. This partly underscore why most FDI inflows go to the extracting sector, and giving the absence of any deliberate effort by MNCs to develop the informal sector, these products are exported out and imported in as manufactured products.

Natural resource and economic openness are positively related to FDI. We expected the latter to be positively related to FDI because FDI does not flow into an economy in a state of autarky. For natural resource, this finding is akin with earlier studies (Anyanwu, 2011; UNCTAD, 2007; Dinda, 2007). We were not expecting the least from this variable given that the country is richly endowed. This supports why the primary sector receives the largest share in FDI flows in Nigeria.

Finally, human capital development and market size are negatively related with FDI, with both coefficients statistically significant. In relation to human capital and FDI inflows, the negativity seems plausible. MNCs most times require the competence of highly skilled and specialized workers, which are in shortfall in the country, therefore informing their choice of location. However, for market size, previous studies -Anyanwu, 2011; Asiedu, 2005; Anyanwu 1998-affirmed a positive relationship between the variables. Maybe our choice of proxy might have affected such finding. Thus, it is a call for further researches, adopting a better criterion of its measurement, to investigate on this.

\section{Policy Recommendations}

It is in our firmly held conviction that FDI is an important spoke on the wheel of national development, thus its attraction should been given domestic policy prominence. But for this to be achievable, the necessary 
requirements must be met. Therefore, the policy implication of these findings, acting as a pragmatic step in boosting FDI flows in Nigeria, is in an acronym format- $\boldsymbol{F D I}$. They are:

1. Fostering qualitative domestic expenditure in upgrading the nation's infrastructure facilities in all sectors;

2. Demonstrating quality political and economic administrations, especially in the areas of financial development, internal security, and intensify the fight towards reducing corrupt practices; and

3. Instituting a supportive rampart (the social system) for the domestic private sector to grow in an unfathomable proportion.

\section{References}

[1]. Adeolu, B. A. 2007FDI and Economic Growth: Evidence from Nigeria.AERC Research Paper 165.Nairobi: AERC

[2]. Ahmad, G. 2010Analyzing the Relationship between Foreign Direct Investment Domestic Investment and Economic Growth for Pakistan. International Research Journal of Finance and Economics, Issue 47, 1450-2887.

[3]. Anyanwu, Kingsley N. 2011The Impact of Foreign Direct Investment on Nigeria's Economic Growth. (Unpublished Thesis). Anambra, Nigeria: Nnamdi Azikiwe University

[4]. Anyanwu, J.C. 1998.An Econometric Investigation of the Determinants of Foreign Direct Investment in Nigeria:InInvestment in the Growth Process. Proceedings of the Nigerian EconomicSociety Conference 1998, pp. 219-40. Ibadan, Nigeria.

[5]. Asiedu, E. 2005.Foreign Direct Investment in Africa: The Role of Natural Resources, Market Size, Government Policy, Institution and Political Instability.Helsinki: UNU/WIDER Research Paper 2005/24. World Institute for Development Economics Research.

[6]. Assaf, Razin and Efraim, Sadka, 2003.Labor, Capital and Finance: International Flows.Cambridge: Cambridge University Press.

[7]. Central Bank of Nigeria (various years). Central Bank of Nigeria Statistical Bulletin.Abuja: CBN

[8]. Borensztein, E., J., De-Gregorio and J.-W. Lee 1998. How Does Foreign Investment Affect Economic Growth?Journal of International Economics, 45, pp. 115-35.

[9]. Bosworth, B. P. and Collins, S. M 1999.Capital Flows to Developing Economies: Implications for Saving and Investment. Brookings Papers on Economic Activity, 1, pp. 143-69.

[10]. De Mello, L. 1999. Foreign Direct Investment Led Growth: Evidence from Time- Series and Panel Data.Oxford Economic Papers, 51, pp. 133-51.

[11]. Eli A. Udo and Isitua K. Obiora 2006,Determinants of Foreign Direct Investment in the West African Monetary Zone: A System EquationsApproach.Ibadan: University of Ibadan.

[12]. Dinda, S. 2009. Factors Attracting FDI to Nigeria: An EmpiricalInvestigation. Chennai, India: Madras School of Economics,

[13]. Ekpo, A.H. 1997.Foreign Direct Investment in Nigeria: Evidence from time series data. CBN Economic and Financial Review, 35(1): 59-78

[14]. Jhingan, M.L. 2007.International Economics.Delhi: Vrinda Publications Ltd.

[15]. Laura, A. 2003.Foreign Direct Investment and Growth: Does the Sector Matter?U.S.A:Harvard Business School.

[16]. Michael, P. Todaro. and Stephen, C. S.2009.Economic Development. New York :Addision Wesley Publication.

[17]. Ndikumana, LéonceandVerick, Sher 2008The Linkages between FDI and Domestic Investment: Unravelling the Developmental Impact of Foreign Investment in Sub-Saharan Africa. Bonn, Germany: IZA Discussion Papers, No. 3296

[18]. Obida, G.W. and Abu, N. 2010.Determinants of Foreign Direct Investment in Nigeria: An Empirical Analysis. Global Journal of Human Social Science, 10(1), 26-30.

[19]. Okomoh P.F. 2004. The Role of Business in Society: Foreign Direct Investments and their Impact on Sustainable Development in Nigeria. A Paper For2004 World Bank Institute (WBI)/ Wharton Business SchoolInternational research/ Essay Contest on CSR for Future Leaders.

[20]. Olatunji, D 2001. At Home Abroad When Titles Get In The way. Lagos, Nigeria: The Nation Newspapers, Tuesday, September, 25.

[21]. Organization for Economic Co-operation and Development (OECD) 1992: Paris

[22]. Padma M. and Karl P.S. 1999.Foreign Direct Investmentin Developing Countries. Financeand Development Geneva: UNCTAD.

[23]. Rutherford, D. R. 1992Dictionary of Economics.London

[24]. Schumpeter J.A. 1911, The Theory of Economic Development: An Inquiry into Profits, Capital, Credit, Interest and Business Cycle". Cambridge Mass: Harvard University Press.

[25]. UNCTAD 2010.World Investment Report.New York: United Nations.

[26]. UNCTAD 2006.Trade and Investment Report.New York: United Nations.

[27]. Uwubanmwen, Ahmed E.andAjao, Mayowa G. 2012. The Determinants and Impacts of Foreign Direct Investment in Nigeria.International Journal of Business and Management; Vol. 7 (24)

[28]. Wei, Shang-Jin. 2008. How Taxing Is Corruption to International Investors?Review of Economics and Statistics 82(1): 1-11.

[29]. World Bank 1996. World Debt Tables: External Finance for Developing Countries, Vol. 1 (Analysis and Summary Tables). Washington, D.C.: The World Bank. 